\title{
Evaluation of Albuminated Curcumin as Soluble Drug Form to Control Growth of Cancer Cells in Vitro
}

\author{
Christina Thomas, Lakshmi Sreedharan Pillai, Lissy Krishnan* \\ Thrombosis Research Unit, Biomedical Technology Wing, Sree Chitra Tirunal Institute for Medical Sciences \& \\ Technology, Trivandrum, India \\ Email: ${ }^{*}$ lissykk@sctimst.ac.in
}

Received 29 April 2014; revised 25 May 2014; accepted 17 June 2014

Copyright (C) 2014 by authors and Scientific Research Publishing Inc.

This work is licensed under the Creative Commons Attribution International License (CC BY). http://creativecommons.org/licenses/by/4.0/

(c) (i) Open Access

\begin{abstract}
Curcumin (Curc) is well known for its anticancer activity, but its poor solubility in aqueous medium is a major concern for little therapeutic outcome. Therefore, the effort to improve its bioavailability is a major research interest. The current study aimed at conjugation of Curc to serum albumin (Alb) to increase aqueous solubility of the former without affecting its drug action on cancer cell lines and primary cells in culture. Conditions for preparation of albumin-curcumin (Alb-Curc) conjugate were standardized to obtain pure and stable drug. The product was obtained in sufficient quantity to test its effect on cells in culture at different doses. Briefly, the conjugate was prepared by mixing Curc dissolved in DMSO with the Alb dissolved in phosphate buffered saline; conjugate was purified by gel filtration chromatography and was analyzed using UV-Vis spectroscopy for characteristic peaks of both molecules. The conjugate was added to culture medium to identify the effect of conjugate on cell cycling and apoptosis. Albuminated curcumin that showed 100-fold higher solubility than free Curc was stable and inhibitory to proliferation, induced cell cycle arrest and apoptosis. The conjugate showed apoptotic effects on endothelial cells indicating its anti angiogenic property. Primary fibroblast growth was also inhibited but at the higher dose. The in vitro results suggest that Alb-Curc which is free of insoluble native drug may find application in cancer therapy after appropriate in vivo evaluations.
\end{abstract}

\section{Keywords}

Curcumin, Anticancer Drug, Aqueous Solubility, Bioavailability, Albumin Drug Conjugation

\footnotetext{
${ }^{*}$ Corresponding author.
}

How to cite this paper: Thomas, C., Pillai, L.S. and Krishnan, L. (2014) Evaluation of Albuminated Curcumin as Soluble Drug Form to Control Growth of Cancer Cells in Vitro. Journal of Cancer Therapy, 5, 723-734. 


\section{Introduction}

Curcumin (Curc) is a low molecular weight polyphenol obtained from the roots of Curcuma longa. Owing to its wide spectrum of biological functions, the immense potential of curcumin to act against various diseases such as cancer [1], inflammation [2], oxidative stress [3], myocardial infarction [4], pain [5], and rheumatism [6] has been well described. Turmeric has been traditionally used in diet for its aromatic stimulant and coloring properties. It is the main ingredient of composites of different natural materials used for treatment of various ailments such as wounds, inflammation and tumor [7]. So its medicinal use is expected to be safe.

Its low aqueous solubility and resultant low absorption into systemic circulation is the major limitation for clinical success. Extensive work to improve water solubility and enhance therapeutic impact has resulted in encapsulation of Curc into various anionic and cationic micelle systems. Thus drug delivery systems with sodium dodecyl sulfate, cetyl trimethyl ammonium bromide [CTAB] [8], polysaccharides such as 1, 3- $\beta$-glucan [9], polyethylene glycol [10] and cyclodextrin inclusions [11] have been reported. In another approach, water soluble Curc complex was synthesized by dissolving and mixing Curc and gelatin in an aqueous acetic acid solution [12]. With the advent of nanotechnology, attempts have been made to increase the Curc bioavailability by engulfing it with nano carriers [13], polymeric nano particles [14], solid lipid nano particles [15], micelles [16], nano gels [17], nano suspensions [18], nano emulsions, complexes and dendrimer/dimer [19].

All these techniques involve release of Curc from the delivery vehicle which poses a major problem of premature drug release [20]. Though these techniques certainly improved drug targeting, the end results have not been easily translated to clinical practice. Owing to the bigger size of nano particles they are found to be less efficient in passing through the blood vessels and reaching target sites. Also, toxicity of drug carrier becomes another major concern. Albumin, an abundant plasma protein, is an important drug carrier in cancer therapy since numerous preclinical studies have demonstrated its accumulation in experimental solid tumors due to enhanced permeation retention (EPR) effect [21]. The method of conjugating Curc with biodegradable, nontoxic, and non immunogenic Alb could be a suitable method for improving bioavailability of the drug. Studies have been carried out to enhance bioavailability of Curc-Alb nanoparticles [22]. But as compared to leaking of Alb into the tumor tissue, entry of Curc-Alb nano particle into cell is considered to be less efficient. It has been already suggested that Alb accumulates in the tumor tissue as a source of amino acids for the rapid growth of the tumor [23].

Even though the drug conjugation with native Alb has been reported [24], the study has not explored anti cancerous and anti-angiogenesis property of the conjugate. Based on the study that Curc binds to albumin, in this study it has been demonstrated that by a fast, simple reaction albuminated Curc can be obtained at a preparative scale and purified from free drug. The conjugation increased solubility by 100 fold and prevented degradation of the drug. The effect of the conjugated drug on cancer cells was studied in vitro and was found to inhibit growth.

\section{Materials and Methods}

Curcumin, bovine serum albumin (BSA), Sephadex G-25 beads, and dialysis bag of 12,400 MWCO was purchased from Sigma Chemicals (USA). A stock of 0.2 M Curc in DMSO (analytical grade) was prepared and stored at $-20^{\circ} \mathrm{C}$. Working concentrations of $10 \mu \mathrm{M}-2000 \mu \mathrm{M}$ was obtained by adding required volumes of the stock to albumin (Alb) with or without further dilution in DMSO. Albumin was added to PBS and mixed gently to get desired concentration of protein in solution. For checking the effect of $\mathrm{pH}$ on Curc conjugation to Alb, the protein was dissolved in PBS with different $\mathrm{pH}$. To study the effect of Curc concentration on conjugation, different volumes of stock in DMSO was added to same concentration of protein solution to get the desired final concentration of Curc in the reaction mixture. The reaction was allowed to take place for different time intervals and at different temperature to study the effect of reaction length and temperature. Reaction time was terminated by loading the mixture on Sephadex G-25 column for purification of the Alb-Curc conjugate. The Curc-Alb conjugate was identified by measuring the A280:A420 ratio of $1 \mathrm{ml}$ fractions eluted from the column. The protein fractions with minimum spectral peak ratio were considered to have maximum Curc conjugation. The fractions with least A280:A420 ratio were pooled and $1 \mathrm{ml}$ aliquots of the pooled conjugate was lyophilized (Edwards Modulyo, Edwards, UK) and stored at $4^{\circ} \mathrm{C}$. The lyophilized protein was dissolved in water and sterile filtered through $0.22 \mu \mathrm{m}$ syringe filter (Millipore, USA) for further tests. The stability/reversibility of conjugation was tested by keeping the pure Alb-Curc in dialysis bag for 48 h, and by checking the spectral properties of 
contents in the dialysis bag and the dialysate. To extract Curc from the conjugate, the lyophilized Alb-Curc conjugate was dissolved in $0.05 \mathrm{ml}$ water, and Lowry's protein concentration per unit volume was determined. Then Curc in the dissolved conjugate was extracted by adding $0.95 \mathrm{ml}$ DMSO. The concentration of Curc in the conjugate was estimated using a calibration curve constructed with standards prepared by adding different volumes of the original stock into DMSO and by measuring respective absorbance at $420 \mathrm{~nm}$ using 8053 Hewlett Packard Diode Array spectrophotometer (USA). The concentration of bound Curc per unit weight of the protein was calculated. Characterization of conjugated product was carried out with UV-visible absorption spectroscopy (diode array spectrophotometer, Hewlett Packard 8453). The sterile conjugate was used to test the effect of AlbCurc on growth of cancer/normal primary cell cultures.

To study the effect of the drug conjugate on cancer cells, Lung (A549), Leukemia (K562) \& Prostate (PC-3) cancer cell lines were procured from NCCS, Pune. On receipt, the cell lines were sub cultured and sufficient stock vials were stored in $-80^{\circ} \mathrm{C}$ deep freezer. To study the effect of Curc on angiogenesis, primary endothelial cells obtained from sheep and characterized as per the method described [25]. To test the effect of Alb-Curc on primary fibroblast, cells were isolated from human foreskin obtained from local hospital (collected with informed consent) using a standard protocol [26]. Cells were sub cultured and either the $3^{\text {rd }}$ or $4^{\text {th }}$ passage monolayer was used for the study. Each cell line was maintained in their respective recommended media. The cell lines A549, PC3 and fibroblast cells were maintained in DMEM media with 10\% FBS. K562 cells were maintained in IMDM media supplemented with 10\% FBS and endothelial cells in MCDB media with 10\% FBS, L-ascorbic acid, VEGF and L-Glutamine. Concentration of drug bound to one mg of albumin was calculated as described above. For adding specific concentration of Alb-Curc, the estimated Lowry's protein of the conjugate was considered which correspond to calculated quantity of bound Curc.

About $1 \times 10^{6}$ numbers of A549, PC3, K562, endothelial cells and fibroblasts were seeded into $25 \mathrm{~cm}^{2}$ culture flasks in appropriate growth media supplemented with 10\% FBS and antibiotics. After $24 \mathrm{~h}$ of growing cells in the culture, Alb-Curc complex was added to get the desired final concentration. After incubating cultures with the drug for $24 \mathrm{~h}, 48 \mathrm{~h}$, or $72 \mathrm{~h}$, the cells were collected in ice cold PBS and were spun down at $200 \mathrm{~g}$ for $7 \mathrm{~min}$. Ice cold $70 \%$ ethyl alcohol was added to the cell pellet and vortex mixed gently. The cells were fixed for $45 \mathrm{~min}$ at $4^{\circ} \mathrm{C}$, and again were spun down at $200 \mathrm{~g}$ for $7 \mathrm{~min}$. The pellet was resuspended in $1 \mathrm{ml}$ PBS and the spinning was repeated once more. Finally, the pellet was resuspended in $250 \mu \mathrm{l} \mathrm{PBS}, 5 \mu \mathrm{l}$ of $10 \mu \mathrm{g} / \mathrm{ml}$ RNAseA was added and incubated for $30 \mathrm{~min}$ at $37^{\circ} \mathrm{C}$. Ten $\mu \mathrm{l}$ of $1 \mathrm{mg} \cdot \mathrm{ml}^{-1}$ PI was added to the cells, kept in dark for $5 \mathrm{~min}$, mixed with $250 \mu \mathrm{l}$ PBS and was analyzed using FACS Aria (BD Science, USA). The analysis was done using Flowjo software (Version 7.6.5).

Binding of Annexin V to the exposed phosphatidyl serine of mitochondrial membrane and Propidium Iodide (PI) to nucleus of dead cells were studied using Alexa Fluor 488 Annexin V/Dead cell Apoptosis kit (InvitrogenMolecular Probes). About $5 \times 10^{5}$ cells of A549, PC3, K562, endothelial cells and fibroblasts were seeded per $10 \mathrm{~cm}^{2}$ area in 6-well plates and were grown in appropriate growth media supplemented with $10 \%$ FBS and antibiotics. After $24 \mathrm{~h}$, Alb-Curc was added into the culture plates and incubated for $24 \mathrm{~h}, 48 \mathrm{~h}$ and $72 \mathrm{~h}$. Negative (PBS) and positive controls (doxrubicin) were also included for each cell culture experiment. The concentration of Doxorubicin used was $2 \mu \mathrm{M}$ [27]. After the treatment period, the cells were harvested and processed as per reagent manufacturer's instruction for flow cytometry (FACS Aria, BD Science, USA) to estimate apoptosis.

\section{Results}

Stable Alb-Curc with good solubility in aqueous medium was obtained by mixing Alb and Curc at specific $\mathrm{pH}$ and temperature. Conjugation of Curc to Alb was not efficient at $\mathrm{pH}$ higher than 7.4. When Alb concentration was low in the mixture, lot of free Curc remained in the mixture which was retained in the column upon gel filtration on Sephadex G25 column. Washing with 30\% ethanol was required to remove such retained Curc from the Sephadex G25 beads, which may be due to the poor solubility of Curc in PBS. So when Curc was in excess in reaction mixture, the amount of free drug that retained on the column was high. But when the Alb concentration was increased to $50 \mathrm{mg} \cdot \mathrm{ml}^{-1}, 80 \%$ of the Curc which was added to the reaction mixture was bound to Alb and the conjugate was eluted in the void volume of the column.

The eluted pure fractions of Alb-Curc with highest protein content (high $A_{280}$ ) were found to have lowest $\mathrm{A}_{280}: \mathrm{A}_{420}$ ratio, depending on the Curc concentration. Thus ratio was influenced by the concentration of Curc in the reaction mixture. When the Alb concentration used was fixed at $50 \mathrm{mg} \cdot \mathrm{ml}^{-1}$ and Curc was $<200 \mu \mathrm{M}$, the ratio was closer to 10 . But when Curc was increased, the protein rich fraction showed reduction in $\mathrm{A}_{280}: \mathrm{A}_{420}$ ratio 
and showed $\sim 1.0$ with $2000 \mu \mathrm{M}$ Curc (Figure 1). Therefore, for subsequent experiment, the conjugate was prepared by mixing $50 \mathrm{mg}$ Alb per ml with $2000 \mu \mathrm{M}$ Curc. The conjugation efficiency was tested at $\mathrm{pH}$ 6.8, 7.4, 8.0 and 9.0; the best conjugation was obtained at $\mathrm{pH}$ 7.4. The reaction was allowed to take place at $4^{\circ} \mathrm{C}, 22^{\circ} \mathrm{C}$ and $37^{\circ} \mathrm{C}$. The conjugation was equally efficient at $22^{\circ} \mathrm{C}$ and $37^{\circ} \mathrm{C}$, but was poor at $4^{\circ} \mathrm{C}$. Further, $22^{\circ} \mathrm{C}$ was fixed for producing the conjugate. There was no difference in conjugation efficiency when the incubation of reaction mixture was varied from $1 \mathrm{~h}$ to $4 \mathrm{~h}$. Therefore, $1 \mathrm{~h}$ incubation was fixed for obtaining the conjugate for further experiments. The UV-Vis spectrum of the final standardized Alb-Curc is shown in Figure 1. The lyophilized Alb-Curc showed color difference depending on the extent of drug conjugation (Figure 2(A)). Maximum color is seen in the conjugate prepared by mixing $50 \mathrm{mg} \cdot \mathrm{ml}^{-1}$ Alb with $2000 \mu \mathrm{M}$ Curc. The lyophilized powder was readily soluble in water and the redissolved conjugate is shown in Figure 2(B). It is obvious that the solution is clear unlike that of nano particles of Alb-Curc that has been reported in the literature [22]. Upon extraction of

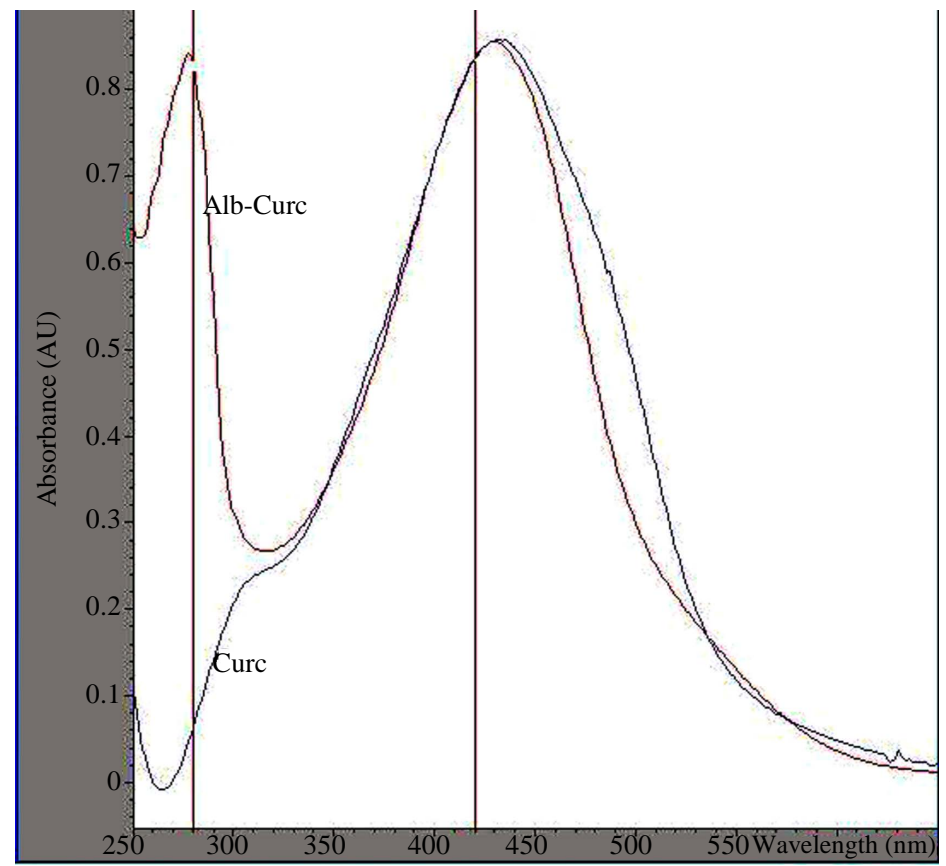

Figure 1. UV-Vis spectra. Tracings shown are of curcumin and Alb-Curc. The Alb-Curc was the product purified by gel filtration chromatography. Peak height of Curc and Alb-Curc are almost the same.
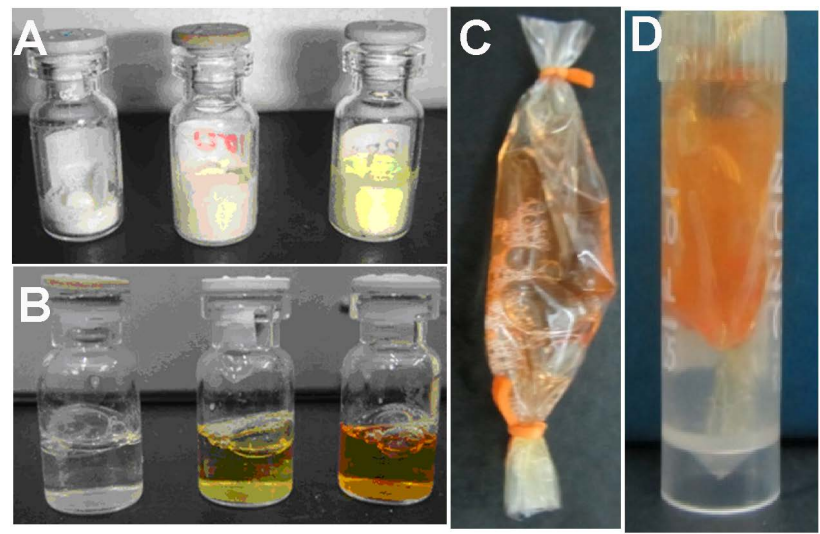

Figure 2. Final product. (A) Lyophilized Alb-Curc with different binding ratio; (B) Re-dissolved Alb-Curc after lyophilization; (C) Alb-Curc filled in dialysis bag to carryout equilibrium dialysis; (D) Clear dialysis fluid after $45 \mathrm{~h}$ of dialysis against PBS at $4^{\circ} \mathrm{C}$. 
Curc from the conjugate using DMSO, the extracted drug was found to be $70 \%$ to $80 \%$ of the originally added quantity (Table 1). Therefore, it may be concluded that even when the albumin is in surplus, $20 \%$ to $30 \%$ of Curc was not conjugated to albumin. The reason is not clear; probably some amount get degraded during the $1 \mathrm{~h}$ incubation period. Figure 2(C) shows that after dialysis for 48 h, no free curcumin leaked into the dialysate; upon analysis by spectrophotometer any characteristic spectral property of Curc or its degradation product was not detected. Therefore, it may be assumed that the conjugation of Curc to Alb is irreversible and the product is stable for more than 5 days.

Known concentration of Alb (measured by Lowry's protein) was added in order to obtain required quantity of Curc in the culture medium. Concentrations of Curc (Alb-Curc) available to react with cell cultures were varied from $25 \mu \mathrm{M}$ to $100 \mu \mathrm{M}$, and in some cases till $1000 \mu \mathrm{M}$. The conjugate was incubated for different periods such as $24 \mathrm{~h}, 48 \mathrm{~h}$ and $72 \mathrm{~h}$ with the cells in cultures. The response of cells to Alb-Curc varied from cell to cell. Effect was studied by three methods: 1) morphology \& density of treated cells in cultures; 2) flow cytometry to estimate apoptotic and dead cell using Annexin V and PI stained cells, respectively; and 3) cell cycle profile using flow cytometry of PI stained samples. Negative control (untreated cultures) and positive control (Doxorubicin treated) cells were included in all three analysis methods.

The morphology analysis showed clear indication of cell death in all 3 cancer cells that were exposed to AlbCurc. There was obvious dose response in all cases. In Figure 3, PC3 cells are shown: both negative and positive controls are included along with 4 different dose of Alb-Curc. The effect of highest dose of Alb-Curc was more prominent and was coming closer to that of cells treated with positive control. By the flow cytometry analysis for Annexin V stained and PI stained cells, no apoptosis was detected at lower concentration but both at $50 \mu \mathrm{M} \& 100 \mu \mathrm{M}$ Alb-Curc, 10\% PC3 cells were Annexin V positive (Figure 4).

Effect of Alb-Curc on A549 is evident from the micrographs in Figure 5. The cell morphology has changed and density has reduced with $50 \mu \mathrm{M}$ Alb-Curc and more prominent effect which is closer to positive control is seen with $100 \mu \mathrm{M}$ drug. On analysis of apoptosis, the effect was similar to that is seen in PC3 cells; no detectable effect was seen in $50 \mu \mathrm{M}$ treated A549 but about $20 \%$ cells stained positive with Annexin V when $100 \mu \mathrm{M}$ conjugate was added. When exposure time was increased to $48 \mathrm{~h}$ or $72 \mathrm{~h}$, the effect was more prominent with more PI stained cells and Annexin V stained cells. But if dose was increased to $250 \mu \mathrm{M}$, more cell death occurred (not shown). Quantifiable cycle arrest was also noted with $100 \mu \mathrm{M}$ of Alb-Curc in PC3 cells and A549 cells (Figure 6). Typically, in cell cycle analysis of conjugate-treated cells, SubG1 phase arrest and S Phase arrest was evident. In apoptosis assay, PI stained cells appeared only with prolonged incubation such as $48 \mathrm{~h}$ or 72 $\mathrm{h}$ in most of the cases. Figure 7 shows micrographs of K652 cells treated with the drug for $24 \mathrm{~h}$. The response of these cells to Alb-Curc was much less and $500 \mu \mathrm{M}$ was required to reduce the cell density which further reduced with $1000 \mu \mathrm{M}$. Apoptosis was not detected in flow cytometric measurement with Annexin V or PI stained cells. Cell cycle arrest was also not detected. Even though the cell density was reduced with $1000 \mu \mathrm{M}$ Alb-Curc treated cultures, cells appeared to be viable as compared to the cells in positive control.

When primary cells were treated with Alb-Curc, concentrations above $50 \mu \mathrm{M}$ showed effect on morphology of EC. When concentration was increased to $100 \mu \mathrm{M}$, cell morphology and density was much affected. With 250 $\mu \mathrm{M}$ free Curc no significant morphology change of EC culture was observed (Figure 8(A)) whereas with 250 $\mu \mathrm{M}$ Alb-Curc, all cells were rounded up in $24 \mathrm{~h}$ (Figure 8(D)). Apoptosis was evident in flow cytometry; both Annexin V and PI stained cells were estimated to be significant when Alb-Curc concentration was above $50 \mu \mathrm{M}$, treated for $24 \mathrm{~h}$. Isotypic control and $100 \mu \mathrm{M}$ Alb-Curc treated cell analysis data were acquired. As compared to control $\sim 50 \%$ more cells stained positive for Annexin V, when ECs were treated with $100 \mu \mathrm{M}$ Alb-Curc. Cell cycle arrest was also significant with similar range of drug concentrations. Morphological changes to primary human fibroblasts were also seen with the conjugated drug (Figure 9). The major difference was that there was

Table 1. Conjugation efficiency. Out of added curcumin the quantity conjugated to albumin was extracted using DMSO, after gel filtration and lyophilization of eluted conjugate.

\begin{tabular}{cc} 
Curcumin quantity added $(\mu \mathrm{M})$ & Curcumin extracted into DMSO $(\mu \mathrm{M})$ \\
50 & 38 \\
250 & 184 \\
500 & 368 \\
1000 & 735 \\
\hline
\end{tabular}




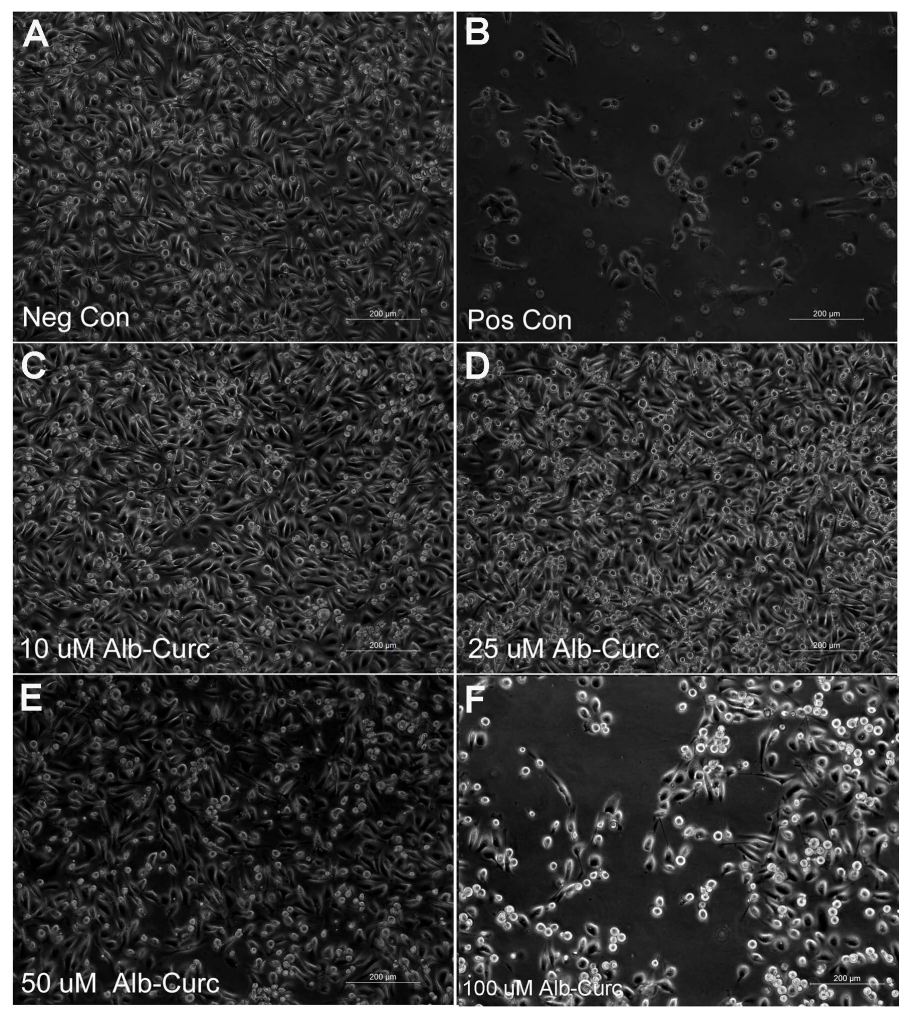

Figure 3. Representative photomicrographs of PC3 cultures. Cultures were treated with the drug after it became confluent. Graded concentration of drug added to each well is indicated in the image. The cell density is the least and similar to positive control ( $2 \mu \mathrm{M}$ Doxorubicin) when Alb-Curc added was $100 \mu \mathrm{M}(\mathrm{F})$. All images were taken at the same magnification. Scale bar is shown at the right hand corner of each image.
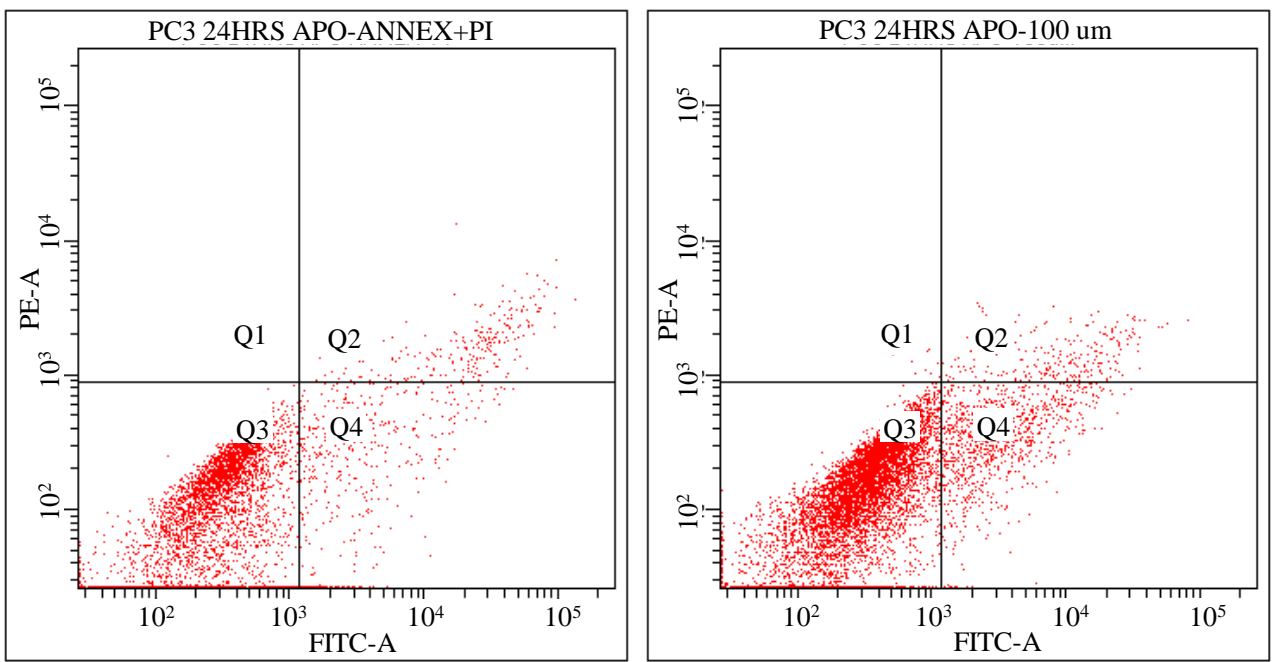

Figure 4. Representative dot plot of apoptosis assay. The data shown is of PC3 cells and the concentration of the drug conjugate added is shown in the graph. The assay was done after $24 \mathrm{~h}$ incubation of the drug with PC3 culture. FITC conjugated Annexin V and PI staining was done as per the manufacturers' instruction. Control cells stained with the reagent kit is shown and increase of apoptotic cell in Q4 and dead cell in Q1 and apoptotic dead cells in Q2 were compared to that of the stained negative control for each period and each drug concentration. 


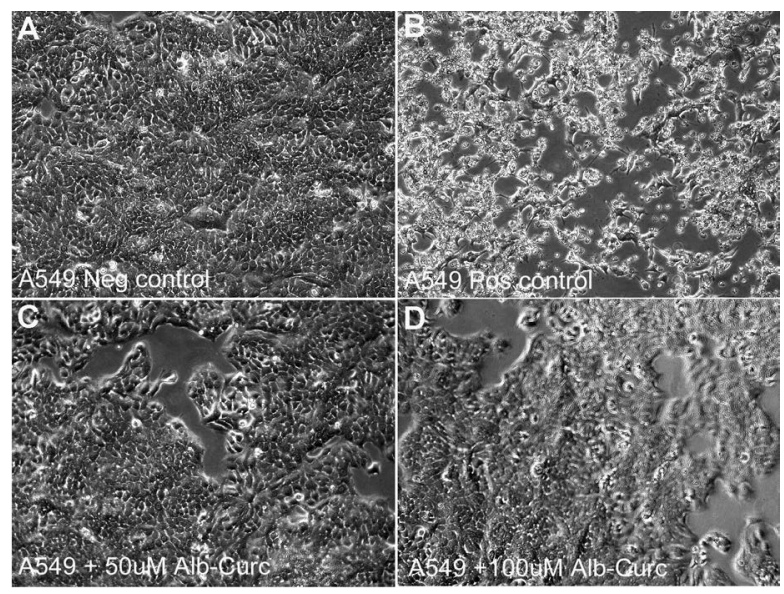

Figure 5. Photomicrographs of A549 cultures. Cultures were treated with the drug after it became confluent. Concentration of Alb-Curc added is indicated in the image. All images were taken at the same magnification.
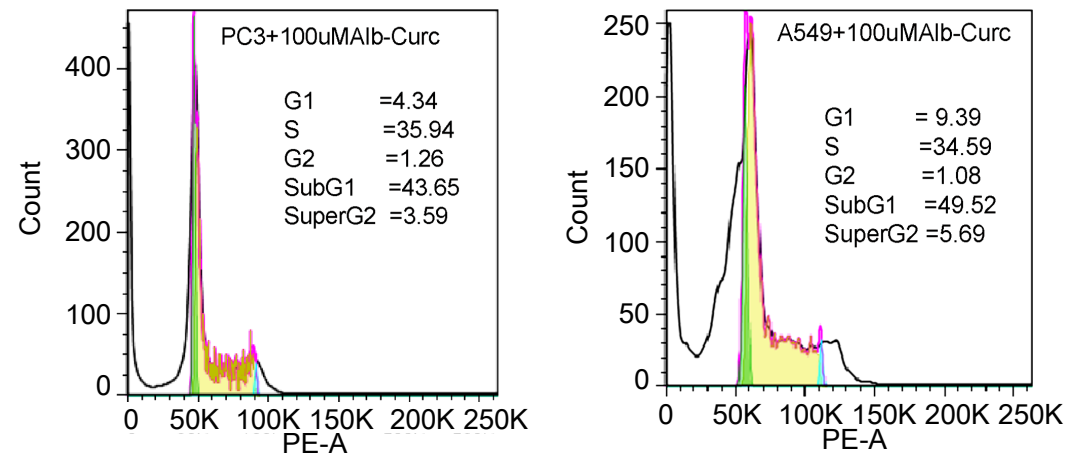

Figure 6. Representative histograms of cell cycle analysis. Histograms acquired in FACS Aria and analyzed by Flojo software are shown. The cell type and concentration of drug used are indicated in the respective image. Cells in the log phase were treated with drug for $24 \mathrm{~h}$ and cycle was analyzed. The percentage of cells in each phase of cell cycle for respective cell type is also shown in the image.

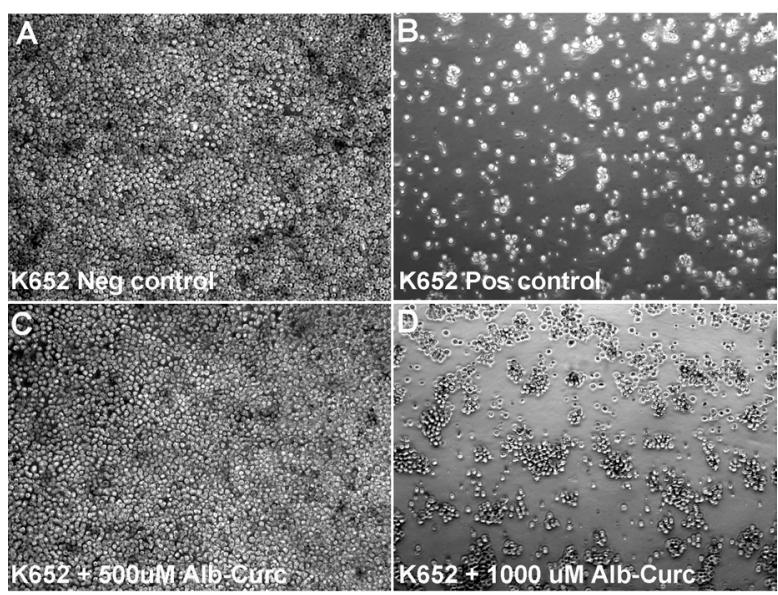

Figure 7. Photomicrographs of K652 cultures. Cultures were treated with the drug after it became confluent. Concentration of Alb-Curc added is indicated in the image. All images were taken at the same magnification. 


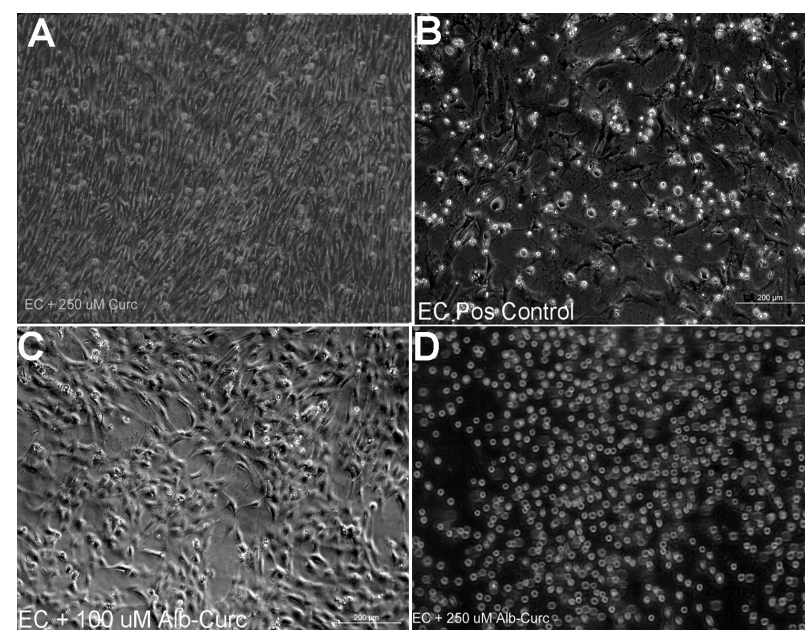

Figure 8. Representative photomicrographs of EC cultures. Monolayers of EC were treated with each drug type. (A) EC treated with $250 \mu \mathrm{M}$ of free Curc added into the culture from the DMSO stock ( $2.5 \mu \mathrm{l}$ of $0.2 \mathrm{M}$ stock to $2 \mathrm{ml}$ cult ure medium) - there is minimal effect with few round cells; (B) Positive control into which doxorubicin $(2 \mu \mathrm{M})$ was added; (C) EC treated with $100 \mu \mathrm{M}$ Alb-Curc; (D) EC treated with 250 $\mu \mathrm{M}$ Alb-Curc. All monolayers were treated with respective drug for $24 \mathrm{~h}$.

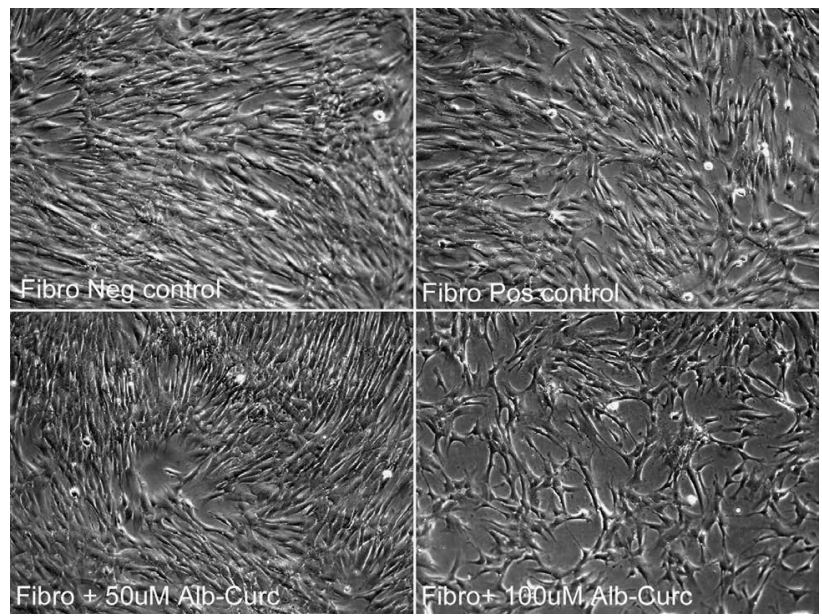

Figure 9. Representative photomicrographs of fibroblast cultures. Monolayers of fibroblast were treated with drug concentrations as shown in the image. Untreated monolayer is the negative control and doxorubicin $(2 \mu \mathrm{M})$ treated culture is the positive control. All photographs were taken at the same magnification. The drug was treated with cells for $24 \mathrm{~h}$ in each case.

no effect when $50 \mu \mathrm{M}$ concentrations were added to fibroblast; lower concentration such as $25 \mu \mathrm{M}$ Alb-Curc affected EC density/morphology. The concentration which showed morphological changes to primary cells also induced apoptotic effect and cell cycle arrest in flow cytometric analysis. So, cell-to-cell difference in inhibitory effect, especially dose response is seen which were detected qualitatively by morphological changes and cell density, and quantitatively by cell cycle analysis and apoptosis assay. Effect of Doxorubicin was more aggressive, all cells were rounded up within $24 \mathrm{~h}$ and in apoptosis assay majority of the cells were positive for PI; some were positive for both Annexin V and PI. Normal unstained cells were hardly seen. So, the results suggests 
that Alb-Curc effect on both cancer cells and normal primary cells was dose dependant but less aggressive as compared to doxorubicin.

\section{Discussion}

Curcumin mediates apoptotic and anti-proliferative effects on cancer cells, including cancer stem/progenitor cells and their progenies. Molecular mechanisms of drug action have been well understood. Therefore, Curc has been subjected to several clinical trials for its application as a therapeutic agent for various diseases including cancer. However, its poor solubility in aqueous medium is a major reason for little therapeutic outcome. Currently, development of effective drug delivery system for Curc is a major research interest. The objective of this study was to conjugate Curc to the plasma protein, Alb to increase the aqueous solubility of Curc. The conjugate was purified by gel filtration chromatography on Sephadex G25 column by removing free/unbound Curc. The parameters to obtain the best product were established by changing conditions of conjugation such as $\mathrm{pH}$, time/ temperature of reaction and concentration of reactants. Stability of binding was established by dialysis and testing for free Curc in the dialysate. Finally, biological activity of Alb-Curc on cancer cell lines and primary human cells was tested in in vitro cell cultures. Albuminated curcumin that has 100-fold higher solubility than the native Curc was obtained. The product is free from native Curc or other synthetic chemicals thus making it a safe material for human use. The Alb-Curc remained stable for $>5$ days without any signs of conversion to its metabolites in culture medium.

Albumin is a well established drug carrier. Since both human and bovine serum albumin is structurally similar, BSA was used in this study. There have been several attempts to covalently conjugate drug molecule, proteins and peptides to albumin to increase their stability. The rationale for such attempts is increased accumulation of albumin in solid tumors. Many of such attempts have reached final stages of clinical trials. Albumin accumulates in tumor tissue due to leaky vasculature or due to faulty lymphatic system. Accumulation of serum proteins of different size in solid tumor has been described in the literature [28]. Anti cancer drugs that have been conjugated to Alb include methotrexate and two pro-drugs of doxorubicin. The conjugate of doxo derivatives with albumin has been shown to be easy to prepare and the product has antitumor efficacy [29]. In this study we attempted to produce conjugate of Curc with Alb. Though Curc is a proven drug for many different activities such as anticancer, anti-inflammatory and anti angiogenesis, the major problem in the clinical use of the drug is its poor solubility in aqueous medium. So increasing the solubility of the drug without affecting biochemical properties of the molecule may have immense potential for its use as therapeutic agent.

The most attractive observation is that Curc was bound to Alb in simple reaction mixture and there was no requirement of any chemical modification that would affect the integrity of protein or the drug. Free Curc was removed from the reaction mixture using simple separation technique to ensure that the properties relates to the conjugate only. The spectral properties of both drug and protein are clearly evident and the spectral peak ratio decreased corresponding to the extent of drug binding. Normally, if $2000 \mu \mathrm{M}$ of Curc is added to $1 \mathrm{ml}$ buffer the drug precipitates, but when it is added to $1 \mathrm{ml}$ Alb solution containing $50 \mathrm{mg}$ protein, there was no precipitation of Curc. This indicates that the binding reaction is quick. The kinetics of reaction is so fast that there was not much Curc trapped in Sephadex G25 beads also. But if Curc was in excess and protein was less, there were plenty of unbound molecules stuck to the column. With $50 \mathrm{mg} \cdot \mathrm{ml}^{-1}$ Alb, majority of added drug was bound to the Alb, till Curc concentration was $2000 \mu \mathrm{M}$. Thus the standardized conditions of Alb-Curc conjugate preparation is easy and can be scaled up for commercial preparation of the drug.

The increased solubility was obvious even with naked eye; a very intense yellow colored clear solution of the conjugate was obtained. Its stability is proven by the equilibrium dialysis experiment. Conjugate did not show any spectral changes with time, indicating the stability of complex and moreover, the lyophilization has not affected the resolubility. All these finding suggests that Alb-Curc can be prepared in industrial scale and will have long term shelf life and stability in lyophilized form. Albumin being a natural protein of plasma, it can be infused safely for therapeutic application. In experimental animals bearing solid tumours radioactively-or fluorescently labelled albumin was taken up specifically into tumours [30]. The same specific uptake of albumin into inflamed joints of mice in the collagen induced arthritis model similar to that into tumour tissue was seen [31], emphasizing the similarity of physiological processes in inflammation and tumour growth. Therefore, the product that was developed in this study has potential applications as a therapeutic agent for various indications.

It is demonstrated that the product developed in this study is not necrotic to cells. Apoptosis and cell cycle ar- 
rest of cancer cells and normal human cells took place in a dose-dependent manner. Inhibition of proliferation by Curc was observed in neuroglial cells with a concentration as low as $5 \mu \mathrm{M}$ by day 6, while inhibition of 20 $\mu \mathrm{M}$ doses occurred by day 2 of culture [32]. In another study with HT29 cells, $30 \mu \mathrm{M}$ to $100 \mu \mathrm{M}$ concentration of curcumin dissolved in DMSO showed inhibitory effect on gene expression [33]. There are several reports showing dose dependant effect of curcumin on cancer cells and most of the studies showed inhibitory effect on cellular and molecular pathways. We also observed dose dependant effects using similar range of concentration that are reported. So conjugation of the drug with Alb has not reduced the efficacy to act on cells. Dose of doxorubicin used in this study showed inhibition of cell growth in all cases. In vitro study results may not be directly applicable for in vivo use, especially to detect the therapeutic efficacy. Therefore, in vivo studies are required to prove the dose requirement for control of tumour growth by Alb-Curc. Due to the poor solubility and absorption to plasma, no study has been reported to show the therapeutically effective concentration range. With achievement of soluble Curc conjugate which may be transfused, prospect of identifying effective concentration should be more realistic.

Other than the action seen on cancer cells, control of primary endothelial cell growth and apoptosis indicates that the conjugate has potential for use as anti angiogenic drug. Interestingly, $250 \mu \mathrm{M}$ of free Curc (in DMSO) added into the EC culture did not affect the cobblestone morphology of the cells, whereas the same concentration of Alb-Curc has made drastic change in EC morphology. The lack of inhibitory action may be related to poor miscibility/solubility of the drug in to the culture medium. The effect of Alb-Curc was less on fibroblast as compared to cancer cells and endothelial cells, which is an additional attraction because normal tissue may be less affected as compared to cancer tissue. The results of this study give clear indications of maintenance of the biological activity of Curc even after it is stably conjugated to albumin. Several-fold increase in solubility is an attractive feature of the Alb-Curc for increasing the bio availability of the drug for applications in clinical medicine.

\section{Conclusion}

In conclusion, the preparation of soluble Curc was achieved by conjugating the drug with albumin. Solubility was extensively enhanced. Conjugation was found to stabilize the drug. Even after albumin conjugation, Curc was found to be active; cell proliferation was impeded as indicated by the reduced cell density, changed cell morphology and stimulated apoptosis and cell death. Cell cycle arrest was observed in all cases except the K652 (leukemia) cells. Effect of free Curc was negligible, whereas the same concentration of the conjugate affected all cells in the culture well and cells were rounded off. Conjugated drug could be anti angiogenic as the endothelial cells were affected by it. Effect of cells on normal fibroblast was much less as compared to cancer cells and endothelial cells. Major advantage of the product is that the bioavailability is not dependent on release from the delivery vehicle; albumin with drug will get endocytosed by cells for inducing the drug action. Alb-Curc has promising potential as anticancer and anti angiogenic molecule, which requires the further study to understand pharamacodynamics and pharmacokinetics before it can be used in clinical conditions.

\section{Acknowledgements}

The authors acknowledge the Director SCTIMST Trivandrum, and Head BMT wing for their valuable support. Authors would like to acknowledge ICMR, Government of India, for funding the research. We would like to acknowledge our colleagues Mr. Ranjith S for helping with the flow cytometry analysis.

\section{References}

[1] Aggarwal, B.B. and Shishodia, S. (2006) Molecular Targets of Dietary Agents for Prevention and Therapy of Cancer. Biochemical Pharmacology, 71, 1397-1421. http://dx.doi.org/10.1016/j.bcp.2006.02.009

[2] Jurenka, J.S. (2009) Anti-Inflammatory Properties of Curcumin, a Major Constituent of Curcuma Longa: A Review of Preclinical and Clinical Research. Alternative Medicine Review, 14, 141-153.

[3] Ruby, A.J., Kuttan, G., Babu, K.D., Rajasekharan, K.N. and Kuttan, R. (1995) Anti-Tumour and Antioxidant Activity of Natural Curcuminoids. Cancer Letters, 94, 79-83. http://dx.doi.org/10.1016/0304-3835(95)03827-J

[4] Morimoto, T., Sunagawa, Y., Kawamura, T., Takaya, T., Wada, H., Nagasawa, A., et al. (2008) The Dietary Compound Curcumin Inhibits p300 Histone Acetyltransferase Activity and Prevents Heart Failure in Rats. Journal of Clinical Investigation, 118, 868-878. 
[5] Sundarananthavalli, S., Kulandaisamy, A. and Christopher, C.C. (2011) Synthesis, Characterisation, Analgesic, Antiinflammatory, Anti-Ulcer, Wound Healing and Antimicrobial Effects of Curcuminoids. International Journal of ChemTech Research, 3, 2040-2046.

[6] Shishodia, S., Sethi, G. and Aggarwal, B.B. (2005) Curcumin: Getting Back to the Roots. Annals of the New York Academy of Sciences, 1056, 206-217. http://dx.doi.org/10.1196/annals.1352.010

[7] Sharma, R.A., Gescher, A.J. and Steward, W.P. (2005) Curcumin: The Story So Far. European Journal of Cancer, 41, 1955-1968. http://dx.doi.org/10.1016/j.ejca.2005.05.009

[8] Leung, M.H.M., Colangelo, H. and Kee, T.W. (2008) Encapsulation of Curcumin in Cationic Micelles Suppresses Alkaline Hydrolysis. Langmuir, 24, 5672-5675. http://dx.doi.org/10.1021/la800780w

[9] Huong, L.M., Thu, H.P., Thuy, N.T.B., Ha, T.T.H., Thi, H.T.M., Trang, M.T., et al. (2011) Preparation and Antitumor-Promoting Activity of Curcumin Encapsulated by 1,3- $\beta$-Glucan Isolated from Vietnam Medicinal Mushroom Hericium erinaceum. Chemistry Letters, 40, 846-848. http://dx.doi.org/10.1246/cl.2011.846

[10] Kim, C.Y., Bordenave, N., Ferruzzi, M.G., Safavy, A. and Kim, K.H. (2011) Modification of Curcumin with Polyethylene Glycol Enhances the Delivery of Curcumin in Preadipocytes and Its Antiadipogenic Property. Journal of Agricultural and Food Chemistry, 59, 1012-1019. http://dx.doi.org/10.1021/jf103873k

[11] Yadav, V.R., Prasad, S., Kannappan, R., Ravindran, J., Chaturvedi, M.M., Vaahtera, L., et al. (2010) CyclodextrinComplexed Curcumin Exhibits Anti-Inflammatory and Antiproliferative Activities Superior to Those of Curcumin through Higher Cellular Uptake. Biochemical Pharmacology, 80, 1021-1032. http://dx.doi.org/10.1016/j.bcp.2010.06.022

[12] Rezq, E.A.M., Mansour, M.T.A.-A. and Al-Malki, A.L. (2011) Gelatin, a Curcumin Drug Carrier System. World Patent WO 2011/100984 A1.

[13] Alam, S., Panda, J.J. and Chauhan, V.S. (2012) Novel Dipeptide Nanoparticles for Effective Curcumin Delivery. International Journal of Nanomedicine, 7, 4207-4222.

[14] Bisht, S., Feldmann, G., Soni, S., Ravi, R., Karikar, C., Maitra, A., et al. (2007) Polymeric Nanoparticle-Encapsulated Curcumin ("Nanocurcumin”): A Novel Strategy for Human Cancer Therapy. Journal of Nanobiotechnology, 5, 3. http://dx.doi.org/10.1186/1477-3155-5-3

[15] Vandita, K., Shashi, B., Santosh, K.G. and Pal, K.I. (2012) Enhanced Apoptotic Effect of Curcumin Loaded Solid Lipid Nanoparticles. Molecular Pharmacology, 9, 3411-3421. http://dx.doi.org/10.1021/mp300209k

[16] Wang, K., Zhang, T., Liu, L., Wang, X., Wu, P., Chen, Z., Ni, C., Zhang, J., Hu, F. and Huang, J. (2012) Novel Micelle Formulation of Curcumin for Enhancing Antitumour Activity and Inhibiting Colorectal Cancer Stem Cells. International Journal of Nanomedicine, 7, 4487-4497.

[17] Mangalathillam, S., Rejinold, N.S., Nair, A., Lakshmanan, V.K., Nair, S.V. and Jayakumar, R. (2012) Curcumin Loaded Chitin Nanogels for Skin Cancer Treatment via the Transdermal Route. Nanoscale, 4, 239-250. http://dx.doi.org/10.1039/c1nr11271f

[18] Gao, Y., Li, Z., Sun, M., Li, H., Guo, C., Cui, J., Li, A.G., Cao, F.L., Xi, Y.W., Lou, H.X. and Zhai, G.X. (2010) Preparation, Characterization, Pharmacokinetics, and Tissue Distribution of Curcumin Nanosuspension with TPGS as Stabilizer. Drug Development and Industrial Pharmacy, 36, 1225-1234. http://dx.doi.org/10.3109/03639041003695139

[19] Yallapu, M.M., Ebeling, M.C., Chauhan, N., Jaggi, M. and Chauhan, S.C. (2011) Interaction of Curcumin Nanoformulations with Human Plasma Proteins and Erythrocytes. International Journal of Nanomedicine, 6, 2779-2790.

[20] Kwon, I.K., Lee, S.C., Han, B. and Park, K. (2012) Analysis on the Current Status of Targeted Drug Delivery to Tumors. Journal of Controlled Release, 164, 108-114. http://dx.doi.org/10.1016/j.jconrel.2012.07.010

[21] Kratz, F. (2008) Albumin as a Drug Carrier: Design of Prodrugs, Drug Conjugates and Nanoparticles. Journal of Controlled Release, 132, 171-183. http://dx.doi.org/10.1016/j.jconrel.2008.05.010

[22] Kim, T.H., Jiang, H.H., Youn, Y.S., Park, C.W., Tak, K.K., Lee, S., Kim, H., Jon, S., Chen, X.Y. and Lee, K.C. (2011) Preparation and Characterization of Water-Soluble Albumin-Bound Curcumin Nanoparticles with Improved Antitumor Activity. International Journal of Pharmaceutics, 403, 285-291. http://dx.doi.org/10.1016/j.ijpharm.2010.10.041

[23] Kratz, F. and Elsadek, B. (2012) Clinical Impact of Serum Proteins on Drug Delivery. Journal of Controlled Release, 161, 429-445. http://dx.doi.org/10.1016/j.jconrel.2011.11.028

[24] Kunwar, A., Barik, A., Pandey, R. and Priyadarsini, K.I. (2006) Transport of Liposomal and Albumin Loaded Curcumin to Living Cells: An Absorption and Fluorescence Spectroscopic Study. Biochimica et Biophysica Acta, 1760, 1513-1520. http://dx.doi.org/10.1016/j.bbagen.2006.06.012

[25] Sreerekha, P.R., Divya, P. and Krishnan, L.K. (2006) Adult Stem Cell Homing and Differentiation in Vitro on Composite Fibrin Matrix. Cell Proliferation, 39, 301-312. http://dx.doi.org/10.1111/j.1365-2184.2006.00389.X

[26] Ma, L., Gao, C.Y., Mao, Z., Zhou, J., Shen, J., Hu, X.Q. and Han, C.M. (2003) Collagen/Chitosan Porous Scaffolds 
with Improved Biostability for Skin Tissue Engineering. Biomaterials, 24, 4833-4841. http://dx.doi.org/10.1016/S0142-9612(03)00374-0

[27] Sadeghi-Aliabadi, H., Minaiyan, M. and Dabestan, A. (2010) Cytotoxic Evaluation of Doxorubicin in Combination with Simvastatin against Human Cancer Cells. Research in Pharmaceutical Sciences, 5, 127-133.

[28] Matsumura, Y. and Maeda, H. (1986) A New Concept for Macromolecular Therapeutics in Cancer Chemotherapy: Mechanism of Tumoritropic Accumulation of Proteins and the Antitumor Agent Smancs. Cancer Research, 46, 63876392.

[29] Drevs, J., Esser, N., Richly, H., Skorzec, M., Scheulen, M.E., Unger, C., et al. (2000) In Vivo Activity and Pharmacokinetic Study of an Acid-Sensitive Doxorubicin Albumin Conjugate in a Urine Renal Cell Carcinoma in Comparison to Free Doxorubicin. Clinical Cancer Research, 6, 120.

[30] Stehle, G., Sinn, H., Wunder, A., Schrenk, H.H., Schutt, S., Maier-Borst, W. and Heene, D.L. (1997) The Loading Rate Determines Tumor Targeting Properties of Methotrexate-Albumin Conjugates in Rats. Anticancer Drugs, 8, 677-685.

[31] Wunder, A., Muller-Ladner, U., Stelzer, E.H., Funk, J., Neumann, E., Stehle, G., Pap, T., Sinn, H., Gay, S. and Fiehn, C. (2003) Albumin-Based Drug Delivery as Novel Therapeutic Approach for Rheumatoid Arthritis. Journal of Immunology, 170, 4793-4801. http://dx.doi.org/10.4049/jimmunol.170.9.4793

[32] Ambegaokar, S.S., Wu, L., Alamshahi, K., Lau, J., Jazayeri, L., Chan, S., Khanna, P., Hsieh, E. and Timiras, P.S. (2003) Curcumin Inhibits Dose-Dependently and Time-Dependently Neuroglial Cell Proliferation and Growth. Neuro Endocrinology Letters, 24, 469-473.

[33] Van Erk, M.J., Teuling, E., Staal, Y.C.M., Huybers, S., Van Bladeren, P.J., Aarts, J.M.M.J.G. and van Ommen, B. (2004) Time- and Dose-Dependent Effects of Curcumin on Gene Expression in Human Colon Cancer Cells. Journal of Carcinogenesis, 3, 8. http://dx.doi.org/10.1186/1477-3163-3-8 